\title{
PAWEE LENIO
}

Uniwersytet Wrocławski

pawel.lenio@uwr.edu.pl

\section{Źródła finansowania ochrony zdrowia w Polsce i w Niemczech ${ }^{1}$}

\author{
Sources of health care financing \\ in Poland and Germany
}

Streszczenie. Artykuł dotyczy problematyki publicznoprawnych źródeł finansowania ochrony zdrowia w Polsce i w Niemczech. Systemy zdrowotne w wymienionych państwach finansowane są przede wszystkim z wpływów z tytułu składki na ubezpieczenie zdrowotne. Mają one także inne źródła finansowania, do których zalicza się środki publiczne wydatkowane $\mathrm{z}$ budżetu centralnego. W opracowaniu ustalono zatem podobieństwa i różnice $\mathrm{w}$ finansowaniu polskiego i niemieckiego systemu ochrony zdrowia oraz przedstawiono wnioski de lege ferenda w odniesieniu do polskich regulacji prawnych.

Słowa kluczowe: ochrona zdrowia; finanse publiczne.

Abstract. This paper focuses on public sources of a healthcare financing in Poland and in Germany. These systems are based primarily on the health insurance

1 Opracowanie przygotowane w ramach projektu pt. „Źródła finansowania ochrony zdrowia w Polsce - aspekty prawne” finansowanego w konkursie PRELUDIUM 8 organizowanym przez Narodowe Centrum Nauki (nr projektu: 2014/15/N/HS5/01735). 
contributions. In Poland and in Germany a healthcare is also financed from state budgets. Author identified differences and similarities in the examined healthcare financing systems. This paper also includes conclusions de lege ferenda regarding Polish law.

Keywords: healthcare; public finance.

\section{Wstęp}

Przedmiotem badań w niniejszym opracowaniu są regulacje prawne determinujące rodzaje źródeł finansowania ochrony zdrowia w Niemczech i w Polsce. Niemcy jako jedno z pierwszych państw utworzyły system ochrony zdrowia o charakterze publicznoprawnym funkcjonujący w formie ubezpieczenia zdrowotnego. Jest on finansowany w zasadniczej części ze składek ubezpieczeniowych. Niemieckie ubezpieczenie zdrowotne powołano jeszcze w XIX w. Niemcy są zatem jednym z najbardziej doświadczonych państw w zakresie organizacji publicznoprawnego systemu opieki zdrowotnej. Przedstawienie niemieckich rozwiązań prawnych jest uzasadnione ze względu na to, że polski system zdrowotny oparty jest o ubezpieczeniową metodę finansowania. Jego zasadniczym przychodem jest bowiem składka na ubezpieczenie zdrowotne.

Celem niniejszego opracowania jest wskazanie najistotniejszych różnic w zakresie konstrukcji prawnej publicznoprawnych źródeł finansowania ochrony zdrowia w Niemczech i w Polsce. Porównanie regulacji normatywnych dotyczących finansowania systemów zdrowotnych we wskazanych państwach umożliwi sformułowanie wniosków de lege ferenda w zakresie rozwiązań legislacyjnych obowiązujących w Polsce.

Funkcjonowanie w państwach Unii Europejskiej systemów organizacyjnych ochrony zdrowia o zróżnicowanym charakterze oraz odmiennych zasadach finansowania jest uzależnione przede wszystkim od realiów społecznych i politycznych poszczególnych krajów. Możliwość autonomicznego kształtowania zasad finansowania systemów ochrony zdrowia wynika z prawa pierwotnego UE. Nie ingeruje ono bowiem w wewnętrzne regulacje prawne dotyczące katalogu źródeł finansowania ochrony zdrowia. 


\section{2. Źródła finansowania ochrony zdrowia w Niemczech}

Niemiecki model ochrony zdrowia funkcjonuje w oparciu o ustawowe ubezpieczenie zdrowotne (Gesetzliche Krankenkversicherung - GKV). Jest on elementem systemu ubezpieczeń społecznych, w skład którego wchodzą także ubezpieczenie wypadkowe, emerytalne, od bezrobocia i pielęgnacyjne. Do cech współczesnego niemieckiego modelu ochrony zdrowia zalicza się przede wszystkim: funkcjonowanie ustawowych instytucji ubezpieczeniowych w formie kas chorych jako instytucji autonomicznych zawierających mowy ze świadczeniodawcami na realizację świadczeń na rzecz ubezpieczonych, istnienie Funduszu Zdrowia, do którego przekazywane są składki zdrowotne obciążające ubezpieczonych i ich pracodawców, a także transfer pobranych składek do poszczególnych kas chorych oraz możliwość wyboru kasy przez ubezpieczonego ${ }^{2}$. Podstawą prawną funkcjonowania niemieckiego ustawowego ubezpieczenia zdrowotnego jest Księga Piąta Kodeksu Socjalnego ${ }^{3}$.

Niemieckie ustawowe ubezpieczenie zdrowotne jest finansowane zasadniczo z dwóch źródeł. Głównym źródłem są przychody z tytułu opłacanych przez członków kas chorych składek ubezpieczeniowych. Źródłem o mniejszym znaczeniu fiskalnym są środki pochodzące z budżetu federacyjnego, w tym środki otrzymywane przez Fundusz Zdrowia na podstawie $\S 221$ ust. 1 i 2 SGB V ${ }^{4}$.

W myśl § 220 ust. 1 SGB V system ubezpieczenia zdrowotnego jest finansowany ze składek, w tym składek dodatkowych oraz pozostałych wpływów. Prognozowana wysokość wpływów zasilających ustawowe ubezpieczenie zdrowotne ustalana jest przez zespół do spraw szacunków

2 Kancelaria Senatu, Biuro Analiz i Dokumentacji, Dział Analiz i Opracowań Tematycznych, Finansowanie niemieckiego systemu opieki zdrowotnej, listopad 2010, s. 3 i 5, www.senat.gov.pl (dostęp: 30.12.2017 r.).

3 Sozialgesetzbuch (SGB) Fünftesbuch (V) - Gesetzliche Krankenversicherung vom 20 Dezember 1988 (BGBl. I S. 2477); dalej powoływany jako „SGB V”.

4 Wykluczone jest finansowanie ustawowego ubezpieczenia zdrowotnego ze środków pochodzących z budżetów krajów związkowych. P. Axer, Komentarz do § 271, [w:] W. Eichenhofer, U. Wenner (red.), Kommentar zum Sozialgesetbuch V, Kolonia 2013, s. 1756. 
funkcjonujący przy Federalnym Urzędzie do Spraw Ubezpieczeń (Bundesversicherungsamt $)^{5}$.

Do elementów konstrukcji prawnej niemieckiej składki na ubezpieczenie zdrowotne należy zaliczyć przede wszystkim podstawę jej wymiaru oraz stawkę składki ${ }^{6}$. Niemiecki ustawodawca nie wyróżnia w sposób jednoznaczny przedmiotu składki. Przedmiot ten wynika jednak z tytułów do objęcia obowiązkowym ubezpieczeniem zdrowotnym oraz przynależnością do danej kasy (członkostwem). W specyficzny sposób został uregulowany podmiot składki zdrowotnej. W zasadzie zakres podmiotowy niemieckiej składki na ubezpieczenie zdrowotnej jako kosztu partycypowania w obowiązkowym ubezpieczeniu zdrowotnym obejmuje osoby będące członkami danej kasy chorych ${ }^{7}$.

Sposób ustalania podstawy wymiaru składki zdrowotnej jest uzależniony od poszczególnych tytułów ubezpieczeniowych. Największą grupę ubezpieczonych stanowią pracownicy. Podstawą wymiaru składki w ich przypadku jest wynagrodzenie otrzymywane z tytułu zatrudnienia objętego obowiązkowym ubezpieczeniem. Drugi element konstrukcji prawnej niemieckiej składki mający zasadnicze znaczenie dla zasad obliczania jej wysokości to stawka składki ${ }^{8}$. W przypadku zdecydowanej większości osób ubezpieczonych wynosi ona $14,6 \%$ podstawy wymiaru (§ 241 SGB V).

5 Zespół do 15 października oszacowuje wysokość przewidywanych: wpływów od objętych ubezpieczeniem obowiązkowym członków kas chorych, rocznych wpływów na rzecz Funduszu Zdrowia, a także rocznych wydatków ponoszonych przez kasy chorych oraz liczbę ubezpieczonych oraz członków kas. Szacowana wysokość przedstawionych parametrów dotyczy danego oraz przyszłego roku (§ 220 ust. 2 SGB V).

6 Na temat konstrukcji prawnej niemieckiej składki zdrowotnej zob. szerzej: P. Lenio, Składka w polskim i niemieckim systemie ubezpieczenia zdrowotnego, „Prawo Budżetowe Państwa i Samorządu” 2017, nr 1, s. 61-82, DOI: http://dx.doi.org/10.12775/PBPS.2017.004.

7 Wyjątek stanowią pracownicy. Są oni zobowiązani do opłacania części składki na ubezpieczenie zdrowotne. Na podstawie § 249 ust. 1 SGB V połowę wysokości składki ponosi pracodawca zatrudniający pracownika.

8 Kasy chorych są uprawnione do pobierania dodatkowej składki od swoich członków oraz ustalania we własnym zakresie jej stawki na podstawie § 242 ust. 1 SGB V. Przesłanką do ich żądania jest niepokrycie zapotrzebowania danej kasy z dotacji otrzymanych z Funduszu Zdrowia. P. Axer, Komentarz do § 271..., s. 1753. 
W ustawowym ubezpieczeniu zdrowotnym zasadą jest, że zobowiązanym do odprowadzenia składki jest ten, kto ponosi jej koszty (§ 252 ust. 1 SGB V). Jest to podstawowa norma determinująca zasady opłacania składek zdrowotnych. Przepisy § 253-256 SGB V wprowadzają jednak szereg wyjątków. Skutkiem tego jest fakt, że w przypadku większości ubezpieczonych składkę zdrowotną odprowadza płatnik (np. pracodawca za pracowników) ${ }^{9}$.

Zróżnicowany jest także sposób dokonywania płatności składki. W większości przypadków jest ona uiszczana na rachunek odpowiedniej jednostki pobierającej składkę. Właściwość danej jednostki nie wynika z przepisów o ustawowym ubezpieczeniu zdrowotnym. Jest ona ustalana na podstawie regulacji prawnych zawartych w SGB IV (w szczególności $\S 28$ i SGB IV).

Jak to już ustalono drugim, obok składki na ubezpieczenie zdrowotne, istotnym źródłem finansowania systemu ochrony zdrowia w Niemczech jest budżet federacyjny. Zgodnie z art. 120 ust. 1 zd. 4 Ustawy Zasadniczej ${ }^{10}$ Federacja pokrywa dopłaty do ciężarów z tytułu ubezpieczenia społecznego z uwzględnieniem ubezpieczenia od bezrobocia i pomocy dla bezrobotnych. Wynika z niego ciążący na państwie obowiązek pokrycia ewentualnego deficytu występującego w niemieckim systemie zdrowotnym. W związku z tym wskazuje się, że dochody ustawowego ubezpieczenia zdrowotnego mogą być uzupełniane tzw. gwarancją federalną, która stanowi jednak pewnego rodzaju ultima ratio. Powołany przepis nie wyklucza jednocześnie finansowania ubezpieczenia zdrowotnego ze środków budżetu federacyjnego pochodzących z dotacji ${ }^{11}$.

Ogólna wysokość dotacji federalnej wynika bezpośrednio z § 221 ust. 1 SGB V. W myśl powołanego przepisu państwo zobowiązane jest do przekazywania do Funduszu Zdrowia zryczałtowanej rekompensaty wy-

$9 \quad$ H. Peters, Komentarz do § 252, [w:] K. Engelmann, R. Schlegel (red.), Sozialgesetzbuch Fünftes Buch - Gesetzliche Krankenversicherung, Saarbrücken 2012, s. 3509.

10 Ustawa Zasadnicza dla Republiki Federalnej Niemiec z 23 maja 1949 r. (BGBl. I S. 2248).

11 S. Rixen, Der Sozialversicherungs beitrag als Basis dere finanziellen Funktionsfähigkeit der gesetzlichen Krankenversicherung [w:] H. Sodan, Handbuch des Krankenversicherungsrechts, Monachium 2014, s. 1082. 
datków kas chorych na świadczenia pozaubezpieczeniowe w wysokości 14,5 mld euro rocznie. Dotychczas zryczałtowana rekompensata wynosiła: 10,5 mld euro za 2014 r., 11,5 mld euro za 2015 r. i 14 mld euro za 2016 r. Kwota 14,5 mld euro ma zastosowanie od 2017 r. W formie ustawy określono zatem wysokość środków publicznych przeznaczanych w celu współfinansowania ustawowego ubezpieczenia zdrowotnego pochodzących z budżetu federacyjnego. Tego rodzaju dotacja federalna umożliwia wprowadzenie przez poszczególne kasy chorych składki na ubezpieczenie zdrowotne w stawce dodatkowej z pewnym opóźnieniem, a także wpływa w sposób stabilizujący na gospodarkę finansową publicznego systemu zdrowotnego $^{12}$. Przychody kas chorych pochodzące $\mathrm{z}$ dotacji federalnej pozwalają na stabilizację przychodów kas. W przypadku braku środków finansowych w wysokości niezbędnej do pokrycia kosztów udzielanych świadczeń w ramach systemu repartycyjnego kasy mają możliwość podjęcia decyzji o wprowadzeniu składki zdrowotnej w stawce dodatkowej z odpowiednim wyprzedzeniem $^{13}$.

Dla funkcjonowania ustawowego ubezpieczenia zdrowotnego istotne znaczenie ma istnienie Funduszu Zdrowia, z którego kasy chorych otrzymują dotacje na pokrycie kosztów swojej działalności (§ 270 SGB V). Ustanowienie Funduszu Zdrowia z dniem 1 stycznia 2009 r. spowodowało istotną zmianę w strukturze przepływu środków finansowych w ubezpieczeniu zdrowotnym. W poprzednim stanie prawnym kasy chorych były podmiotami uprawnionymi do wydatkowania środków pochodzących ze składek opłacanych przez swoich członków. Obecnie obowiązujące przepisy SGB V wprowadzają redystrybucję przychodów z tytułu składek na ubezpieczenie zdrowotne przez Fundusz Zdrowia. Przychody ze składek zdrowotnych służą pokryciu całości wydatków kas chorych oraz są przeznaczane na utworzenie rezerwy płynności, o której mowa w § 271 ust. 2 SGB V. Istnieje zatem zespolenie sytuacji finansowej wszystkich kas chorych poprzez funkcjonowanie Funduszu Zdrowia ${ }^{14}$.

12 R. Mack, Komentarz do $§ 221$ [w:] K. Engelmann, R. Schlegel (red.), Sozialgesetzbuch Fünftes Buch..., s. 3256.

13 Tamże.

14 S. Rixen, Der Sozialversicherungs beitrag..., s. 1082. 
Fundusz Zdrowia jest zobowiązany do przekazywania odpowiedniej części otrzymanych z budżetu federacyjnego środków na rzecz poszczególnych kas chorych w wysokości przypadającego na daną kasę udziału. Kwota dotacji obliczana jest na podstawie stosunku liczby ubezpieczonych we właściwej kasie do liczby ubezpieczonych we wszystkich ka$\operatorname{sach}^{15}$.

Częściowe finansowanie ustawowego ubezpieczenia zdrowotnego $\mathrm{z}$ budżetu państwa nie stanowi wyjątkowej sytuacji. Inne gałęzie niemieckiego systemu ubezpieczeniowego również są dofinansowywane z budżetu centralnego (np. ubezpieczenie emerytalne). Możliwość przekazywania środków publicznych z budżetu federalnego w celu dofinansowania kosztów funkcjonowania ustawowego ubezpieczenia zdrowotnego była analizowana przez Federalny Trybunał Konstytucyjny (Bundesverfassungsgericht). Za zgodne z regulacjami konstytucyjnymi uznano przekazywanie z budżetu centralnego środków w formie dotacji federalnej na rzecz ustawowego ubezpieczenia. Nie uprzywilejowuje ono bowiem kas chorych w stosunku do prywatnych instytucji ubezpieczeniowych funkcjonujących na rynku ubezpieczeń zdrowotnych. Przepisy SGB V mają na celu jedynie wyrównanie obciążeń w obrębie publicznego (ustawowego) ubezpieczenia zdrowotnego, a nie uprzywilejowanie kas chorych, które poprzez dofinansowanie z budżetu centralnego nie muszą wprowadzać wyższych obciążeń publicznoprawnych z tytułu obowiązku uiszczania składki przez swoich członków ${ }^{16}$.

Niemiecki system ubezpieczenia zdrowotnego może być również finansowany z innych źródeł. Wynika to wprost z § 220 ust. 1 SGB V. Do katalogu pozostałych przychodów systemu zalicza się przede wszystkim kary pieniężne, odsetki z zwłokę z tytułu zobowiązań pieniężnych, a także roszczenia odszkodowawcze ${ }^{17}$. Mają one jednak marginalne znaczenie dla struktury przychodów systemu.

15 Przy obliczaniu wysokości dotacji brane są pod uwagę dane z roku poprzedzającego rok otrzymania dotacji.

16 Wyrok Federalnego Trybunału Konstytucyjnego z dnia 10 czerwca 2009 r. (1 BVR 706/08).

17 S. Rixen, Der Sozialversicherungs beitrag..., s. 1081-1082; R. Mack, Komentarz do $\S$ 220 [w:] K. Engelmann, R. Schlegel (red.), Sozialgesetzbuch Fünftes Buch..., s. 3249. 
W przypadku dwóch najistotniejszych źródeł finansowania niemieckiego ustawowego ubezpieczenia zdrowotnego istotną rolę pełni Fundusz Zdrowia. Na podstawie § 266 i § 270 GB V dokonuje przydziału środków na rzecz poszczególnych kas chorych w celu finansowania ich wydatków. Kryteriami, na podstawie których dokonywany jest podział środków pozostających w dyspozycji Funduszu Zdrowia, są przede wszystkim wiek i płeć ubezpieczonych oraz ryzyko ubezpieczeniowe. Przekazywanie środków na podstawie wskazanych kryteriów ma na celu równomierny podział struktury ryzyka pomiędzy wszystkimi kasami ${ }^{18}$.

Uiszczone składki ubezpieczeniowe oraz dotacje przysługujące z budżetu federalnego na podstawie § 221 SGB V nie przysługują obecnie poszczególnym kasom chorych. Ich beneficjentem jest Fundusz Zdrowia, stąd istnieje konieczność uzyskiwania przez kasy środków rozdysponowywanych przez Federalny Urząd ds. Ubezpieczeń. Podstawowy przydział środków dotyczy finansowania kosztów świadczeń w ramach ustawowego ubezpieczenia zdrowotnego dla członków danej kasy. Pozostałe wydatki kas chorych finansowane są również z przydziałów pochodzących z Funduszu Zdrowia. Do tego rodzaju wydatków zalicza się przede wszystkim koszty zarządzania oraz administrowania ${ }^{19}$.

Sposób podziału środków przekazywanych na finansowanie świadczeń ubezpieczeniowych realizowanych przez poszczególne kasy oraz kosztów bieżącej ich działalności nie jest dokonywany w oparciu o faktyczne wydatki kas chorych. Podstawą faktyczną podziału środków pochodzących z Funduszu Zdrowia są tzw. standaryzowane dane. Tego rodzaju rozwiązanie zostało wprowadzone w celu uniknięcia konieczności finansowania działalności kas, których zakres wydatków jest dużo wyższy, poprzez podwyższenie przydziału środków gromadzonych w ramach Funduszu Zdrowia ${ }^{20}$. Środki przysługujące kasom chorych w ramach przydziałów, o których mowa w § 266 i § 270 SGB V, są przekazywane w formie miesięcznych płatności oraz rocznego wyrównania.

18 P. Axer, Komentarz do $\S 271 \ldots$, s. 1753.

19 A. Becker, Komentarz do § 270, [w:] K. Engelmann, R. Schlegel (red.), Sozialgesetzbuch Fünftes Buch..., s. 3681.

20 Tamże, s. 3681. 
Jako uzasadnienie dla utworzenia Funduszu Zdrowia w literaturze niemieckiej wskazuje się konieczność zabezpieczenia przychodów ustawowego ubezpieczenia zdrowotnego w sposób trwały. Wynika to z rosnących problemów dotyczących finansowania systemu ochrony zdrowia, które są przede wszystkim skutkiem zmian demograficznych, oraz wzrostem kosztów opieki zdrowotnej spowodowanych medycznym postępem $^{21}$. Skutkiem reform niemieckiego modelu ochrony zdrowia jest zwiększenie nakładów finansowych pochodzących z budżetu centralnego $^{22}$. W literaturze prawa niemieckiego wskazuje się także, iż ustawowe ubezpieczenie zdrowotne może być dotowane ze środków publicznych innych niż przychody z tytułu składki zdrowotnej pochodzących jedynie z budżetu federacyjnego. Nie jest możliwe przekazywanie Funduszowi Zdrowia ani kasom chorych środków publicznych z budżetów krajów związkowych $^{23}$.

Niemieckie landy nie są podmiotami funkcjonującymi w ramach ustawowego ubezpieczenia zdrowotnego. Nie oznacza to jednak, że z ich środków nie są finansowane zadania publiczne z zakresu ochrony zdrowia. Budżety landów są bowiem jednym ze źródeł finansowania działalności szpitali ${ }^{24}$. Koszty udzielania świadczeń zdrowotnych są pokrywane ze środków kas chorych. Wydatki związane z ogólnymi kosztami funkcjonowania szpitali są natomiast finansowane $\mathrm{z}$ budżetów landów ${ }^{25}$.

Dla gospodarki finansowej ustawowego ubezpieczenia zdrowotnego istotne znaczenie ma także obowiązujący zakaz zaciągania kredytów i pożyczek. Zgodnie z § 220 ust. 1 zd. 2 SGB V zaciąganie przez kasy chorych kredytów lub pożyczek jest wyłączone. Są one niedopuszczalnym instrumentem finansowania działalności kas chorych. Wynika to przede wszystkim z zasady, w świetlej której przychodów i kosztów funkcjonowania kasy powinno odbywać się w ramach własnych środków. Wskazuje

\footnotetext{
P. Axer, Komentarz do $\S 271 \ldots$, s. 1754.

Tamże.

Tamże, s. 1756.

M. Jaworzyńska, System opieki zdrowotnej w Niemczech, „Annales UMCS. Sectio H” 2010, t. 44, s. 1006.

25 P. Jończyk, Struktura systemów oraz finansowanie opieki zdrowotnej w Polsce i na świecie, „Master of Business Administration” 2010, nr 2, s. 121.
} 
się, że niedopuszczalne jest także zaciąganie zobowiązań dłużnych w celu sfinansowania przejściowego deficytu ${ }^{26}$. Zakaz ten odnosi się do całego ustawowego ubezpieczenia zdrowotnego. Objęte są nim wszystkie podmioty funkcjonujące $\mathrm{w}$ tym ubezpieczeniu ${ }^{27}$.

$\mathrm{Z}$ tytułu korzystania ze świadczeń w ramach ustawowego ubezpieczenia zdrowotnego pobierane są także opłaty od pacjentów. Obowiązek uiszczania opłat został wprowadzony z dniem 1 stycznia 2004 r. na podstawie $\S 28$ ust 4 i $\S 61$ zd. 2 SGB V. Uiszczane przez pacjentów opłaty nie stanowią rodzaju składki ubezpieczeniowej. Nie są one bowiem związane z oskładkowaniem wynagrodzenia lub innego uzyskiwanego świadczenia, ale dotyczą faktycznego korzystania ze świadczeń zdrowotnych przysługujących $\mathrm{w}$ ramach ustawowego ubezpieczenia zdrowotnego $^{28}$.

\section{3. Źródła finansowania ochrony zdrowia w Polsce}

Zasady organizacji i finansowania ochrony zdrowia w Polsce determinowane są przede wszystkim przepisami rangi konstytucyjnej. Zgodnie z art. 68 ust. 2 Konstytucji Rzeczypospolitej Polskiej ${ }^{29}$ obywatelom, niezależnie od ich sytuacji materialnej, władze publiczne zapewniają równy dostęp do świadczeń opieki zdrowotnej finansowanej ze środków publicznych. Warunki i zakres udzielania świadczeń określa ustawa. Z powołanego przepisu wynika, iż podstawowym źródłem finansowania ochrony zdrowia powinny być publiczne zasoby finansowe. Prawodawca w art. 68 Konstytucji RP nie narzuca w sposób jednoznaczny określonego modelu organizacji i finansowania ochrony zdrowia. Ustalenie szczegółowych zasad w tym zakresie pozostawiono ustawodawcy. Przepisy Konstytucji RP nie wskazują na konkretny zasób środków, z których mają być finansowane

\footnotetext{
R. Mack, Komentarz do § 221..., s. 3250.

S. Rixen, Der Sozialversicherungs beitrag..., s. 1080.

R. Mack, Komentarz do § 221..., s. 3249. Konstytucja Rzeczypospolitej Polskiej z dnia 2 kwietnia 1997 r. (Dz.U. Nr 78, poz.
483 ze zm.), dalej: Konstytucja RP.
} 
świadczenia opieki zdrowotnej. W związku z tym polski system zdrowotny może być oparty m.in. o pierwotne założenia modelu Beverdige’a lub modelu Bismarcka.

Podstawy prawne organizacji i finansowania ochrony zdrowia w Polsce wynikają przede wszystkim z ustawy o świadczeniach opieki zdrowotnej finansowanych ze środków publicznych ${ }^{30}$ oraz ustawy o działalności leczniczej ${ }^{31}$.

Polski system zdrowotny wzorowany jest na rozwiązaniach organizacyjno-finansowych funkcjonujących w modelu Bismarcka. W związku z tym jest on oparty o powszechne obowiązkowe lub dobrowolne ubezpieczenie zdrowotne. Ubezpieczeniu temu podlegają prawie wszystkie grupy zawodowe i społeczne w Polsce. Należy do nich zaliczyć w szczególności: pracowników, zleceniobiorców oraz inne osoby zatrudnione na podstawie pozapracowniczych stosunków zatrudnienia, rolników i ich domowników, osoby prowadzące pozarolniczą działalność gospodarczą, osoby bezrobotne, osoby pobierające zasiłki na podstawie przepisów o pomocy społecznej, osoby duchowne, sędziów i prokuratorów, funkcjonariuszy służb mundurowych, a także studentów i uczestników studiów doktoranckich. Uprawnionymi do uzyskania świadczeń zdrowotnych w ramach publicznego systemu są także świadczeniobiorcy inni niż osoby ubezpieczone wymieni w art. 2 u.ś.o.z.

Organizatorem świadczeń zdrowotnych jest Narodowy Fundusz Zdrowia. Zgodnie z art. 96 ust. 1 u.ś.o.z. jest on państwową jednostką organizacyjną posiadającą osobowość prawną. Do jego zadań należy przede wszystkim przeprowadzanie konkursów ofert, rokowań i zawieranie umów o udzielanie świadczeń opieki zdrowotnej, a także monitorowanie ich realizacji i rozliczanie oraz finansowanie świadczeń zdrowotnych (art. 97 ust. 2 u.ś.o.z.). W zakresie prawnofinansowym jest on odpowiedzialny przede wszystkim za zarządzanie środkami publicznymi pocho-

30 Ustawa z dnia 27 sierpnia 2004 r. o świadczeniach opieki zdrowotnej finansowanych ze środków publicznych (tekst jedn. Dz.U. z 2017 r. poz. 1938 ze zm.), dalej: u.ś.o.z.

31 Ustawa z dnia 15 kwietnia 2011 r. o działalności leczniczej (tekst jedn. Dz.U. z 2018 r. poz. 160 ze zm.), dalej: u.d.l. 
dzącymi z tytułu opłacania składek na ubezpieczenie zdrowotne (art. 97 ust. 1 u.ś.o.z.).

Głównym źródłem finansowania systemu ochrony zdrowia w Polsce jest składka na ubezpieczenie zdrowotne będąca daniną publiczną o charakterze celowym i odpłatnym przeznaczaną a realizację konstytucyjnych zadań państwa z zakresu ochrony zdrowia ${ }^{32}$. Zgodnie z art. 79 ust. 1 u.ś.o.z. składka zdrowotna wynosi obecnie $9 \%$ podstawy jej wymiaru. W przypadku rolników jest ona uzależniona od wielkości prowadzonego gospodarstwa rolnego wyrażonej w hektarach przeliczeniowych i wynosi 1 zł od każdego hektara. Podstawą wymiaru składki zdrowotnej w odniesieniu do większości grup zawodowych jest osiągany w danym miesiącu przychód podatkowy z danego tytułu ubezpieczeniowego lub innego rodzaju świadczenie ekonomicznie zbliżone do instytucji przychodu (np. niektóre zasiłki lub stypendia). Istnieją również grupy ubezpieczonych, których podstawa wymiaru ma charakter zryczałtowany i jej wysokość nie jest uzależniona od indywidualnej zdolności płatniczej podmiotu ponoszącego ciężar podlegania ubezpieczeniu. Przykładowo, zgodnie z art. 81 ust. 2 u.ś.o.z. podstawę wymiaru składki przedsiębiorców stanowi zadeklarowana kwota, nie niższa jednak niż 75\% przeciętnego miesięcznego wynagrodzenia w sektorze przedsiębiorstw w czwartym kwartale roku poprzedniego, włącznie z wypłatami z zysku.

Cechą charakterystyczną konstrukcji prawnej składki na ubezpieczenie zdrowotne jest możliwość odliczenia jej części od kwoty podatku dochodowego od osób fizycznych w wysokości 7,75\% podstawy wymiaru składki. W związku z tym większość ubezpieczonych jest faktycznie obciążona składką zdrowotną w wysokości ok. 1,25\% podstawy jej wymiaru. Ta zasada będzie miała zastosowanie przede wszystkim do osób, które

32 Konstrukcja prawna polskiej składki zdrowotnej nie będzie przedmiotem szerszych badań w niniejszym opracowaniu. Została ona już przedstawiona min. w opracowaniach: P. Lenio, Charakter prawny składki na ubezpieczenie zdrowotne jako źródła finansowania świadczeń opieki zdrowotnej, „Przegląd Prawa i Administracji” 2014, nr 97, s. 99-115; P. Lenio, Ulgi w zapłacie składki zdrowotnej dla przedsiębiorców, „Prawo Budżetowe Państwa i Samorządu” 2014, nr 3, s. 101-113, DOI: http://dx.doi.org/10.12775/PBPS.2014.032; P. Lenio, Health insurance contributions of farmers, [w:] M. Burzec, P. Smoleń (red.), Essential problems with taxation of agriculture, Lublin 2017 r., ss. 399-412. 
osiągają z danego tytułu ubezpieczeniowego przychód w rozumieniu przepisów o podatku dochodowym od osób fizycznych.

Drugim źródłem finansowania ochrony zdrowia w Polsce jest budżet państwa. Wydatki budżetu centralnego przeznaczane na realizację zadań publicznych z zakresu opieki zdrowotnej można podzielić co najmniej na cztery kategorie. Do pierwszej z nich zalicza się nakłady przeznaczane na tworzenie i prowadzenie podmiotów leczniczych oraz finansowanie działalności podmiotów wykonujących działalność leczniczą. Drugim ich rodzajem są środki przeznaczane na finansowania zadań Państwowego Ratownictwa Medycznego ${ }^{33}$. Do trzeciej kategorii wydatków budżetowych można zakwalifikować nakłady przeznaczane na finansowanie niektórych świadczeń opieki zdrowotnej. Do czwartej kategorii wydatków zalicza się natomiast wydatki dokonywane w celu opłacenia składek na ubezpieczenie zdrowotne za niektórych ubezpieczonych. Przepis art. 86 ust. 1 pkt 2-15 u.ś.o.z. zawiera katalog osób ubezpieczonych, na których nie ciąży obowiązek odprowadzania składki zdrowotnej z własnych środków. Do wskazanego katalogu ustawodawca zaliczył m.in. żołnierzy odbywających zasadniczą służbę wojskową, bezrobotnych niepobierających zasiłku lub stypendium, osoby pobierające zasiłek stały z pomocy społecznej, a także aplikantów Krajowej Szkoły Sądownictwa i Prokuratury (niepobierających stypendium).

Zgodnie z art. 6 ust. 1 u.d.l. Skarb Państwa (reprezentowany przez ministra, centralny organ administracji rządowej albo wojewodę) może tworzyć i prowadzić podmioty lecznicze działające m.in. w formie spółek kapitałowych, a także samodzielnych publicznych zakładów opieki zdrowotnej ${ }^{34}$. Wydatki dotyczące tworzenia i prowadzenia podmiotów leczni-

33 Zgodnie z art. 46 ustawy z dnia 8 września 2006 r. o Państwowym Ratownictwie Medycznym (Dz.U z 2017 r. poz. 2195) zadania zespołów ratownictwa medycznego, $\mathrm{z}$ wyłączeniem lotniczych zespołów ratownictwa medycznego, są finansowane z budżetu państwa z części, których dysponentami są poszczególni wojewodowie. Powierzają oni przeprowadzenie postępowania o zawarcie umów z dysponentami zespołów ratownictwa medycznego na wykonywanie zadań zespołów ratownictwa medycznego, zawieranie, rozliczanie i kontrolę wykonania tych umów dyrektorowi właściwego oddziału wojewódzkiego NFZ. Środki na finansowanie umów są przekazywane z budżetu państwa w formie dotacji celowych.

34 Dalej powoływane jako „s.p.z.o.z.” lub „zakłady”. 
czych w formie spółek kapitałowych dotyczyć będą przede wszystkim zakupu i objęcia akcji i udziałów oraz wniesienia wkładów. W przypadku s.p.z.o.z. z budżetu państwa pokrywane jest zadłużenie zakładów na zasadach i w trybie wynikającym z art. 59 ust. 2, 60 lub 72 u.d.l. Z budżetu państwa mogą być także przekazywane podmiotom wykonującym działalność leczniczą środki publiczne w formie dotacji lub na podstawie zawartej umowy w trybie przepisów art. 114-116 u.d.l.

Świadczenia zdrowotne finansowane ze środków publicznych pochodzących z budżetu państwa mają zróżnicowany charakter. Zasadniczym sposobem finansowania świadczeń zdrowotnych z budżetu państwa jest udzielenie Funduszowi dotacji celowej, o której mowa w art. 97 ust. 8 u.ś.o.z. W ten sposób finansowane są przede wszystkim świadczenia opieki zdrowotnej udzielane na podstawie art. 26 ust. 5 ustawy o przeciwdziałaniu narkomanii ${ }^{35}$, art. 10 ustawy o ochronie zdrowia psychicznego ${ }^{36}$, a także art. 6 ust. 1 pkt 5 ustawy o Karcie Polaka ${ }^{37}$. Przepisami ustawy o finansowaniu niektórych świadczeń zdrowotnych w latach 2015-2018 ${ }^{38}$ wprowadzono ryczałtowe zasady udzielania dotacji, o której mowa w art. 97 ust. 8 u.ś.o.z. Zgodnie $\mathrm{z}$ art. 1 ust. 1 powoływanej ustawy NFZ otrzymuje na finansowanie enumeratywnie wymienionych świadczeń zdrowotnych dotację z budżetu państwa w kwocie 320232 tys. zł rocznie. W związku z tym środki przekazywane w celu realizacji niektórych świadczeń zdrowotnych nie odpowiadają ponoszonym przez NFZ kosztom.

Kolejnym źródłem finansowania ochrony zdrowia są budżety jednostek samorządu terytorialnego. Na podstawie art. 9a i 9b u.ś.o.z. z ich środków mogą być finansowane gwarantowane świadczenia opieki zdrowotnej wyłącznie dla mieszkańców danej wspólnoty samorządowej.

35 Ustawa z dnia 29 lipca 2005 r. o przeciwdziałaniu narkomanii (tekst jedn. Dz.U. z 2017 r., poz. 783 ze zm.).

36 Ustawa z dnia 19 sierpnia 1994 r. o ochronie zdrowia psychicznego (tekst jedn. Dz.U. z 2017 r., poz. 882 ze zm.).

37 Ustawa z dnia 7 września 2007 r. o Karcie Polaka (tekst jedn. Dz.U. z 2017 r., poz. 1459 ze zm.).

38 Ustawa z dnia 25 września 2015 r. o finansowaniu niektórych świadczeń zdrowotnych w latach 2015-2018 (Dz.U., poz. 1770). 
Oznacza to, iż NFZ nie jest obecnie jedynym organizatorem i płatnikiem świadczeń opieki zdrowotnej finansowanych ze środków publicznych.

Ponadto z budżetów samorządowych finansowana jest także działalność podmiotów leczniczych, dla których są one podmiotem prowadzą$\mathrm{cym}^{39}$. Budżety j.s.t. są zatem źródłem finansowania zadłużenia s.p.z.o.z., w tym wygenerowanej przez nie straty netto. Z ich środków tworzone są podmioty lecznicze działające w formie spółek kapitałowych. Organy j.s.t mogą także przekazywać podmiotom wykonującym działalność leczniczą środki publiczne w formie dotacji lub na podstawie umowy w trybie i na zasadach określonych w przepisach działu V u.d.l. Środki przekazywane na podstawie powołanych przepisów mogą otrzymywać jedynie podmioty prowadzące działalność leczniczą udzielające świadczeń zdrowotnych finansowanych ze środków publicznych na zasadach wynikających z przepisów u.ś.o.z.

\section{Wnioski}

Jak to już ustalono, polski i niemiecki system funkcjonują w oparciu o ubezpieczeniowy model ochrony zdrowia (model Bismarcka). W związku z tym konstrukcja prawna ich katalogów źródeł finansowania posiada zdecydowanie więcej podobieństw niż różnic.

Główną cechą analizowanych systemów jest oparcie zasad ich finansowania o przychody pochodzące z uiszczanej składki na ubezpieczenie zdrowotne $^{40}$. Niemieckie ustawowe ubezpieczenie zdrowotne oraz zasilająca je składka funkcjonują na podstawie zasady solidarnego finansowania, która wynika z § 3 ust. 1 SGB V. Skutkiem tego jest fakt, że każdy członek kasy chorych zobowiązany jest wnieść „wkład” w postaci uiszczenia składki ubezpieczeniowej. Nie oznacza to jednak, że wkład ten jest

39 Zgodnie z art. 6 ust. 2 u.d.l. j.s.t. mogą tworzyć i prowadzić podmioty lecznicze w formie spółek kapitałowych, jednostek budżetowych lub samodzielnych publicznych zakładów opieki zdrowotnej.

40 Na różnice i podobieństwa ( $\mathrm{w}$ tym wnioski de lege ferenda) polskiej i niemieckiej składki na ubezpieczenie zdrowotne wskazano w opracowaniu: P. Lenio, Składka $w$ polskim i niemieckim systemie... 
taki sam dla każdego ubezpieczonego, co ma fundamentalne znaczenie dla finansów niemieckiego ubezpieczenia zdrowotnego ${ }^{41}$.

Zasada solidarności została rozwinięta w dalszych przepisach SGB V. Przejawem jej realizacji jest ustawowo określony sposób ustalania wysokości składki zdrowotnej, w której najistotniejsze znaczenie ma podstawa jej wymiaru. Jak to już zostało wskazane, w większości przypadków jest ona uzależniona od zdolności płatniczej ubezpieczonego członka kasy. Decydujące znaczenie ma zatem „subiektywna wydajność gospodarcza poszczególnych członków kas”42. Finansują oni bowiem w różnym stopniu ustawowe ubezpieczenie zdrowotne przy takim samym ryzyku ubezpieczeniowym oraz jednolitymi zasadami otrzymywania świadczeń. Powyższe należy również odnieść do polskiego systemu ochrony zdrowia, który w świetle art. 65 pkt 1 u.ś.o.z. także oparty jest o zasadę solidarności społecznej. W polskiej wersji ubezpieczenia zdrowotnego osoby ubezpieczone w różnym stopniu ponoszą koszty funkcjonowania systemu i w większości przypadków wysokość opłacanej składki jest uzależniona od indywidualnej zdolności płatniczej.

Drugim podobieństwem o istotnym znaczeniu jest udział w finansowaniu systemu ochrony zdrowia polskich i niemieckich jednostek samorządu terytorialnego. Po pierwsze, nie są one uprawnione do ponoszenia nakładów finansowych w celu zapewnienia prawidłowego funkcjonowania ubezpieczenia zdrowotnego. Po drugie, z ich środków finansowana jest działalność podmiotów udzielających świadczeń zdrowotnych mimo, że koszty świadczeń powinny być pokrywane w pełni przez właściwe instytucje ubezpieczeniowe. Oznacza to, iż wysokość środków przekazywanych świadczeniodawcom w celu pokrycia kosztów udzielanych ubezpieczonym świadczeń zdrowotnych nie jest wystarczająca. Konieczne jest zatem finansowanie bieżącej działalności podmiotów leczniczych ze środków budżetów samorządowych (landów). Konsekwencją tego jest dokonywanie przez landy oraz polskie j.s.t. w sposób pośredni nakładów

\footnotetext{
S. Rixen, Der Sozialversicherungs beitrag..., s. 1073-1074.

42 F. Hase, Finanzierungssicherung - Vorschläge zur Binnenreform der Sozialversicherung unter Berücksichtigung der verfassungsrechtlichen Vorgaben [w:] D. Felix (red.), Die Finanzierung der Sozialversicherung, Berlin 2007, s. 32.
} 
finansowych w celu zapewnienia prawidłowego funkcjonowania ubezpieczenia zdrowotnego.

Jako kolejne podobieństwo pomiędzy polskim a niemieckim systemem finansowania ochrony zdrowia należy wskazać dokonywanie wydatków publicznych na rzecz ubezpieczenia zdrowotnego pochodzących z budżetu centralnego. W zakresie szczegółów finansowania systemu ubezpieczenia zdrowotnego z budżetu centralnego można jednak wskazać wiele różnic. Po pierwsze, w polskiej wersji powszechnego ubezpieczenia zdrowotnego z budżetu państwa mogą być finansowane co najmniej cztery rodzaje wydatków, w tym szeroki zakres świadczeń zdrowotnych.

Po drugie, z budżetu federacyjnego jest przekazywana ogólna dotacja federalna w kwocie 14,5 mld euro w skali roku. Od roku 2016 r. ma ona charakter stały i nie jest uzależniona od wysokości kosztów ponoszonych przez podmioty funkcjonujące $\mathrm{w}$ ramach ustawowego ubezpieczenia zdrowotnego. Z budżetu federacyjnego nie są natomiast finansowane poszczególne rodzaje świadczeń. Zgodnie z § 220 SGB V z tego budżetu jest przekazywana jedna dotacja federalna na tzw. świadczenia pozaubezpieczeniowe, które nie zostały jednak zdefiniowane. W tym zakresie nie istnieje zatem zróżnicowany katalog dotacji przekazywanych w celu dofinansowania działalności ustawowego ubezpieczenia zdrowotnego. Jest to zasadnicza różnica pomiędzy sposobem finansowania z budżetu centralnego polskiej i niemieckiej wersji ubezpieczenia zdrowotnego.

De lege ferenda należałoby rozważyć rezygnację z dotychczasowych zasad finansowania świadczeń zdrowotnych z budżetu państwa w formie wielu dotacji celowych, których wysokość nie odzwierciedla faktycznych kosztów ich udzielania. Istnieje bowiem możliwość ich zastąpienia jedną dotacją celową na wzór dotacji federalnej stanowiącej formę dofinansowania działalności ustawowego ubezpieczenia zdrowotnego w celu zapewnienia jego prawidłowego funkcjonowania.

Wprowadzenie takiego sposobu wsparcia finansowego powszechnego ubezpieczenia zdrowotnego mogłoby ułatwić sposób rozliczania przez NFZ otrzymanych dotacji, a także skrócić procedurę wydatkowania otrzymanych środków. Znaczna część dotacji celowych otrzymywanych z budżetu państwa nie odpowiada rzeczywistym kosztom realizacji zadań, 
które mają być z niej w całości finansowane. Dotyczy to przede wszystkim dotacji udzielanych w trybie przepisów ustawy o finansowaniu niektórych świadczeń zdrowotnych w latach 2015-2018 ${ }^{43}$.

Drugim rozwiązaniem jest całkowita rezygnacja z tej formy prawnej przekazywania środków publicznych pochodzących z budżetu państwa w celu finansowania niektórych świadczeń zdrowotnych, za których organizację odpowiada Fundusz. W tym przypadku konieczne byłoby jednak zwiększenie przychodów NFZ z tytułu składki na ubezpieczenie zdrowotne kosztem zmniejszenia dochodów budżetu państwa pochodzących z podatku dochodowego od osób fizycznych.

Jako różnicę pomiędzy zasadami finansowania badanych systemów ochrony zdrowia można także wskazać istnienie gwarancji federalnej, o której mowa w art. 120 ust. 1 zd. 4 Ustawy Zasadniczej dla Republiki Federalnej Niemiec. Konstytucja RP nie przewiduje wprost tego rodzaju gwarancji dla systemu zabezpieczenia społecznego, w tym dla ubezpieczenia zdrowotnego. Gwarancja ta istnieje jedynie w odniesieniu do świadczeń z zakresu ubezpieczeń społecznych i ma charakter rangi ustawowej. Zgodnie z art. 2 ust. 3 ustawy o systemie ubezpieczeń społecznych $^{44}$ wypłacalność świadczeń z ubezpieczeń społecznych gwarantowana jest przez państwo. Obecnie nie wydaje się konieczne ustawowe zagwarantowanie przez Skarb Państwa wypłacalności NFZ jako organizatora i płatnika świadczeń zdrowotnych. De lege ferenda należy jednak rozważyć wprowadzenie tego rodzaju gwarancji, która w przyszłości zapewniłaby wypłacalność NFZ w stosunku do świadczeniodawców udzielających świadczeń zdrowotnych w ramach publicznego systemu. Mogłoby to mieć pozytywny wpływ na stabilność finansową systemu ochrony zdrowia.

43 Dane, na podstawie których są one obliczane, pochodzą za lat poprzedzających wejście w życie ustawy. Nie odzwierciedlają zatem faktycznej liczby świadczeniobiorców (niebędących osobami ubezpieczonymi i mogących korzystać ze świadczeń przysługujących w ramach powszechnego ubezpieczenia zdrowotnego), którym udzielone świadczenia finansowane są ze środków pochodzących z dotacji. Brak jest przy tym mechanizmów umożliwiających prawidłowe ustalenie rzeczywistej liczby świadczeniobiorców, których świadczenia mają być finansowane z otrzymanej przez NFZ dotacji celowej.

44 Ustawa z dnia 13 października 1998 r. o systemie ubezpieczeń społecznych (Dz.U. z 2017 r. poz. 1778 ze zm.). 
Zasadniczą różnicą pomiędzy polskim a niemieckim systemem ochrony zdrowia jest pobieranie opłat za korzystanie z niektórych świadczeń w ramach ustawowego ubezpieczenia zdrowotnego (GKV). W polskim systemie ochrony zdrowia tego rodzaju opłaty są pobierane w przypadku korzystania z niepublicznej (prywatnej) opieki zdrowotnej lub albo z tytułu korzystania ze świadczeń zdrowotnych, które nie są finansowane w ramach powszechnego obowiązkowego lub dobrowolnego ubezpieczenia zdrowotnego i nie mają one charakteru opłat publicznych ${ }^{45}$.

Polski system ochrony zdrowia do $2003 \mathrm{r}$. był oparty o ubezpieczenie zdrowotne, które zarządzane było przez kasy chorych. Kasy funkcjonują natomiast nieprzerwanie $\mathrm{w}$ niemieckim ubezpieczeniu zdrowotnym. W obecnym stanie prawnym nie otrzymują one jednak całości przychodów z tytułu składek ubezpieczeniowych opłacanych przez ich członków. Składki zdrowotne zasilają bowiem Fundusz Zdrowia. Dokonuje on przydziału środków z nich pochodzących na rzecz poszczególnych kas chorych w celu finansowania ich wydatków. Przesłanką utworzenia Funduszu Zdrowia była konieczność koordynacji i wyrównywania przychodów kas. Tworząc go, zmniejszono zatem decentralizację systemu zdrowotnego oraz autonomię finansową kas. Powołanie tego rodzaju funduszu może świadczyć o tym, iż kasy chorych nie były w stanie utrzymać równowagi finansowej w ramach uzyskiwanych w sposób samodzielny przychodów. Mając powyższe na uwadze, nie wydaje się zatem uzasadniony powrót do zdecentralizowanego systemu ochrony zdrowia w Polsce funkcjonującego w oparciu o działalność kas chorych.

Cechą charakterystyczną niemieckiego systemu ochrony zdrowia jest także ustawowy zakaz zaciągania pożyczek przez podmioty ustawowego ubezpieczenia zdrowotnego. Wydaje się, że obecnie nie jest uzasadnione wprowadzenie podobnego zakazu w stosunku do podmiotów działających w polskim ubezpieczeniu zdrowotnym, w tym podmiotów leczniczych. Wprowadzenie tego rodzaju zakazu byłoby możliwe dopiero wówczas, gdy środki przekazywane tym podmiotom w związku z zawartymi z NFZ

45 Analiza możliwości wprowadzenia do katalogu źródeł finansowania ochrony zdrowia tego rodzaju opłat wykracza jednak poza ramy przedmiotowe niniejszego opracowania. 
umowami o udzielanie świadczeń zdrowotnych były w pełni wystarczające na pokrycie ich kosztów.

Polski i niemiecki system zdrowotny są także przykładem tego, iż w obecnych realiach społeczno-gospodarczych istnienie jednego źródła finansowania ochrony zdrowia nie jest wystarczające dla zapewnienia prawidłowej realizacji zadań publicznych w tym zakresie.

\section{Bibliografia:}

Axer P., Komentarz do § 271, [w:] Eichenhofer W., Wenner U. (red.), Kommentar zum Sozialgesetzbuch V, Luchterhand Verlag, Kolonia 2013.

Becker A., Komentarz do § 270, [w:] Engelmann K., Schlegel R. (red.), Sozialgesetzbuch Fünftes Buch - Gesetzliche Krankenversicherung, Juris GmbH, Saarbrücken 2012.

Hase F., Finanzierungssicherung - Vorschläge zur Binnenreform der Sozialversicherung unter Berücksichtigung der verfassungsrechtlichen Vorgaben, [w:] Felix D. (red.), Die Finanzierung der Sozialversicherung, LIT Verlag, Berlin 2007.

Jaworzyńska M., System opieki zdrowotnej w Niemczech, „Annales Universitatis Mariae Curie-Skłodowska. Sectio H” 2010, nr 2, s. 995-1007.

Jończyk P., Struktura systemów oraz finansowanie opieki zdrowotnej w Polsce i na świecie, „Master of Business Administration” 2010, nr 2, s. 116-139.

Lenio P., Składka $w$ polskim i niemieckim systemie ubezpieczenia zdrowotnego, „Prawo Budżetowe Państwa i Samorządu” 2017, nr 1, s. 61-82, DOI: http://dx.doi.org/10.12775/PBPS.2017.004.

Lenio P., Charakter prawny składki na ubezpieczenie zdrowotne jako źródła finansowania świadczeń opieki zdrowotnej, „Przegląd Prawa i Administracji” 2014, nr 97, s. 99-115.

Lenio P., Ulgi w zapłacie składki zdrowotnej dla przedsiębiorców, „Prawo Budżetowe Państwa i Samorządu” 2014, nr 3, s. 101-113, DOI: http://dx.doi.org/10.12775/PBPS.2014.032.

Lenio P., Health insurance contributions of farmers, [w:] Burzec M., Smoleń P. (red.), Essential problems with taxation of agriculture, Wydawnictwo KUL, Lublin 2017. 
Mack R., Komentarz do § 221, [w:] K. Engelmann, R. Schlegel (red.), Sozialgesetzbuch Fünftes Buch - Gesetzliche Krankenversicherung, Juris GmbH, Saarbrücken 2012.

Peters H., Komentarz do § 252, [w:] K. Engelmann, R. Schlegel (red.), Sozialgesetzbuch Fünftes Buch - Gesetzliche Krankenversicherung, Juris GmbH, Saarbrücken 2012.

Rixen S., Der Sozialversicherungs beitrag als Basis dere finanziellen Funktionsfähigkeit der gesetzlichen Krankenversicherung, [w:] H. Sodan, Handbuch des Krankenversicherungsrechts, C.H. Beck, Monachium 2014. 